\title{
PACE OF MODAL SHIFTS IN INTERNATIONALIZATION PROCESSES WITHIN A FIRM
}

\author{
Velocidade das alterações modais nos processos \\ de internacionalização na firma
}

\author{
Kátia de Melo Galdino* \\ Sérgio Fernando Loureiro Rezende** \\ Bruce T. Lamont***
}

\section{ABSTRACT}

Our understanding of the temporal dimension of the internationalization of the firm is incomplete at best. Based on this knowledge gap, this article analyzes how the internationalization processes within a firm can be differentiated according to the pace of modal shifts. We built a qualitative, retrospective longitudinal, embedded case of the internationalization of a Brazilian medium-sized firm that established a footprint in 16 foreign markets over nearly three decades. We find that its internationalization processes can be classified into three groups as far as pace is concerned: an Unmovable Internationalization Process, an Inert Internationalization Process and an Accelerated Internationalization Process. We then call attention to a mismatch between the pace of learning and the modal shifts in the firm's internationalization processes. Further, we suggest a new picture of the internationalization of the firm by proposing the existence of a number of internationalization processes that unfold at distinct paces within a single firm.

Keywords: Pace. Internationalization process. Internationalization of SMES. Learning and modal shifts.

\section{RESUMO}

O nosso entendimento sobre a dimensão temporal da internacionalização é ainda bastante incompleto. Com base nessa escassez de conhecimento, o objetivo deste artigo é analisar como os processos de internacionalização na firma podem ser categorizados com base na velocidade das alterações modais. Nós construímos um estudo de caso incorporado de natureza qualitativa e perspectiva longitudinal da internacionalização de uma empresa brasileira de pequeno-médio porte que entrou em 16 mercados estrangeiros ao longo de mais de três décadas. Os resultados indicam que os processos de internacionalização podem ser classificados em três grupos quanto à velocidade: Processo de Internacionalização Imóvel, Processo de Internacionalização Inerte e Processo de Internacionalização Acelerado. Com isso, nós chamamos atenção para a assincronia entre aprendizagem e alteração de modo nos processos de internacionalização da firma. Ademais, nós sugerimos uma nova concepção da internacionalização propondo a existência de vários processos de internacionalização que se desenrolam em velocidades distintas em uma mesma firma.

Palavras-chave: Velocidade. Processo de internacionalização. Internacionalização de MPMES. Aprendizagem e alteração de modo.

\footnotetext{
* Assistant Professor at Georgia Southern University. Ph.D. in Business Administration from Florida State Univer-sity (USA). Email: kdemelogaldino@georgiasouthern. edu. ORCID: 0000-0002-4666-1168

** Adjunct Professor of the Postgraduate Program in Management at Pontifical Catholic University of Minas Gerais (PPGA/PUC Minas). Ph.D. in Marketing from Lancaster University (UK). Email: sflrezende@gmail.com. ORCID: 0000-0002-6439-1544

*** Jim Moran Eminent Scholar in Business Administration. Ph.D. in Business Administration from University of North Caroline at Chapel Hill (USA). E-mail: blamont@business.fsu.edu. ORCID: 0000-0001-7921-8595
} 


\section{INTRODUCTION}

O ne of the most salient features of research on the internationalization of the firm from a behavioral standpoint, in particular the Uppsala model (JOHANSON; VAHLNE, 1977) and its later revisions (JOHANSON; VALHNE, 1990, 2009; VAHLNE; JOHANSON, 2013), is the attention paid not only to foreign market entry, but also to subsequent moves within a particular foreign market (WELCH; PAAVILAINEN-MANTYMAKI, 2014).

Although this stream of research has been very influential on theorizing in the International Business (IB) field (RUGMAN; VERBEKE; NGUYEN, 2011), we suggest that its outputs have been either tested inadequately (WELCH; PAAVILAINEN-MANTYMAKI, 2014) or used for framing empirical investigations rooted in rather different, yet often implicit basis (HOHENTHAL; JOHANSON; JOHANSON, 2014).

The majority of the empirical investigations are either cross-sectional or employ cross-sectional data to advance our understanding of a phenomenon conceptualized as evolutionary: internationalization processes (SHAVER, 2013). Thus, they fail to consider the temporal dimension of such processes (JOHANSON; MARTIN, 2015).

Needless to say, our knowledge of the how and the why aspects of the internationalization process of the firm is far more advanced than that of the when aspects (CASILLAS; ACEDO, 2013; HILMERSSON; JOHANSON, 2016). To some extent, this led Welch and Paavilainen-Mantymaki (2014) to claim that a truly process-based approach is urgently needed so that research on the internationalization of the firm can progress.

A similar claim was made some years ago (e.g. JONES; KHANNA, 2006), but is has seemingly gone unnoticed (CASILLAS, MORENO; ACEDO, 2012). For example, Benito, Pedersen and Petersen (1999, p. 226) state that "one important but largely unexplored issue pertaining to the dynamics of internationalization of firms concerns changes in the mode of foreign operation". More recently, Gao and Pan (2010, p. 1573) have argued that "[...] little research has been devoted to the pace and dynamics of firms' sequential entries". Likewise, Casillas and Acedo (2013, p. 16) assert that "analyzing the pace of a company's internationalization process following its first international activity is still wide open for further research".

Of particular interest is the pace of the internationalization process of the firm ${ }^{1}$. This embryonic literature concentrates on time to internationalize (CHETTY; JOHANSON; MARTIN, 2014), namely, the length of time it takes the firm to enter a foreign market. It also views this temporal dimension as either a dependent (e.g. CASILLAS; MORENO-MENÉNDEZ; 2014) or an independent variable (e.g. KHAVUL; PÉREZ-NORDTVEDT; WOOD, 2010). In the former, scholars examine the effects of factors such as social networks and age on the pace of the internationalizing firm (e.g. CASILLAS; ACEDO, 2013). In the latter, researchers consider pace as an antecedent of a firm's performance in foreign markets (CHETTY; JOHANSON; MARTIN, 2014). Moreover, such studies implicitly assume that the internationalizing firm is a monolithic, undifferentiated actor (NACHUM; SONG, 2011).

1. Even though we use pace throughout the article, here pace is synonymous of speed (VERMEULEN; BARKEMA, 2002). 
In this article, we depart from this tradition. First, we argue that pace does not necessarily equate with time to internationalize (CASILLAS; ACEDO, 2013). Thus, we consider not only the entry mode, but also modal shifts within each foreign market where the firm operates. Second, we contend that selecting pace as either a dependent or an independent variable has favored cross-sectional studies. As mentioned earlier, this research design frequently disregards how a particular temporal dimension (i.e. pace) shapes processes (i.e. internationalization). According to Abbott (2001), static studies have severe limitations in addressing evolutionary phenomena adequately because they compress the events of a sequence into a unit of time. Given that, we follow Kutschker, Baurle and Schmid (1997) and consider pace as one of the building blocks of the internationalization process of the firm. Assuming that pace is an intrinsic part of such process, we can use it to categorize different internationalization processes. Third, we suggest that the internationalizing firm is a differentiated actor (NACHUM; SONG, 2011). Rather than a single, uniform internationalization process, we advocate the existence of multiple internationalization processes within a firm (WELCH; PAAVILAINEN-MANTYMAKI, 2014). Nachum and Song (2011) and Welch and Paavilainen-Mantymaki (2014) contend that the internationalization process of the firm as a whole can be the result of a number of internationalization processes unfolding in different foreign markets.

Against this backdrop, we sought to analyze how the internationalization processes within a firm can be differentiated according to the pace of modal shifts. Hence, our research question is: How can the pace of modal shifts distinguish the internationalization processes within a firm?

We examine this question by tracing the internationalization process of a Brazilian medium-sized firm, CZM, in all the foreign markets where it has operated since its first international experience. This makes the case of CZM an interesting empirical setting. First, it embraces much more than a single foreign market, which is the option most often selected by IB scholars (HADJIKHANI; HADJIKHANI; THILLENIUS, 2014). Second, it is regarded as a "long" process, which is rarely portrayed in IB studies (ZANDER, 1997; PAJUNEN; MAUNULA, 2008). Third, it illustrates the internationalization process of small and medium-sized firms (SMEs) from emerging markets. This empirical choice is under-researched in the IB literature (LAUFS; SCHWENS, 2014).

This article makes the following contributions. First, we show that the internationalization processes within a firm can be differentiated according to the pace of modal shifts. Not only does this finding point to distinct categories of a firm's internationalization processes in terms of pace, but it also draws attention to categories often disregarded by the literature. Second, we identify a possible mismatch between the pace of learning and the pace of modal shifts for some categories of internationalization processes. This result challenges the taken-for-granted assumption of parallel evolution between them. Third, we open room for a new picture of the internationalization of the firm, namely, a conceptualization that takes into account the existence of a number of internationalization processes within a single firm that follow distinct paces in the foreign markets where they are embedded.

In the next section, we review the literature. Then, we explain our methodological choices for the study of the internationalization of CZM. In the following section, we describe 
and analyze our case. The last two sections are devoted to discussing our empirical findings, developing our contributions and reflecting on the limitations of our study.

\section{LITERATURE REVIEW}

\subsection{THE THREE ELEMENTS OF INTERNATIONALIZATION PROCESSES: HOW, WHY AND WHEN}

Process-based research in management studies means tracing events over time with the aim of building trajectories (LANGLEY; SMALLMAN; TSOUKAS; VAN DE VEN, 2013). Briefly, a trajectory is a sequence of interlocked, interdependent events (ABBOTT, 2001) or a cumulative chain of interconnected events forming a discernible pattern (GEORGE; BENNETT, 2005). Scholars such as Abbott (2001) and Langley (1999) recommend paying attention to at least three elements of a trajectory: how, why and when". The "how" element identifies and describes the steps or events in a trajectory (ABBOTT, 2001). The "why" element explains the sequences of steps or events by probing into causes and mechanisms that drive the trajectory towards a particular path (ABBOTT, 1992). And the "when" element emphasizes temporality, such as the order of events and their pace (ABBOTT, 2001).

To some degree, this notion of trajectory lies behind the research on the internationalization of the firm from a behavioral point of view (FORSGREN; HOLM; JOHANSON, 2015). Scholars attempt to use trajectories to describe and explain how, why and when the firm enters and evolves in international spaces (WELCH; PAAVILAINEN-MANTYMAKI, 2014). Although Fortanier and Tulder (2009) call these sequences international trajectories, the label that is most frequently used is internationalization processes (JOHANSON; VAHLNE, 1977).

For Casillas and Acedo (2013), the literature pays unequal attention to the three elements of the internationalization processes. A special emphasis is placed on the "how" aspect of the internationalization process of the firm, corresponding to stages or types of sequences followed by firms in a foreign market. For example, Bilkey and Tesar (1977) suggest a number of exporting development phases. The well-known, but somewhat controversial, establishment chain is another example of this emphasis (JOHANSON; WIEDERSHEIM-PAUL, 1975). Yet, Cuervo-Cazurra (2007) introduces three types of sequences pursued by the so-called multilatinas, that is, multinationals from Latin America.

Kutschker, Baurle and Schmid (1997) posit that this line of investigation focuses on the most visible aspect of internationalization processes, thus leaving behind the drivers that set them in motion. To an extent, this bias is corrected in studies that describe and explain the generative mechanisms of the internationalization process of the firm, that is, the "why" element.

In this regard, the earlier Uppsala studies stand out as they suggest that the internationalization process of the firm is fueled by a self-reinforcing mechanism of market

2. Economic geographers concentrate on the spatial dimension of the sequence of events, corresponding to the where aspect of such sequence (YEUNG, 1988). In terms of the internationalization process of the firm, the concept of psychic distance deals with space and place (JOHANSON; WIEDERHSEIM-PAUL, 1975). Because this discussion goes beyond the scope our article, we refrain from reviewing the literature on psychic distance. 
knowledge development (JOHANSON; VAHLNE, 1977). Later, relationships and networks are taken into account (JOHANSON; VAHLNE, 2009; FORSGREN; HOLM; JOHANSON, 2015). For example, Coviello and Munro (1997) found that relationships between SMEs and overseas partners for new product development played a role in the internationalization process of the firm. Jormanainenn and Koveshnikov (2012) concluded that SMEs from emerging markets relied heavily on networks for internationalization due to scarce resources to deploy abroad.

As we come closer to the third element of the internationalization process of the firm, the "when", perhaps unsurprisingly we discover that our understanding is limited and sketchy (MORGAN-THOMAS; JONES, 2009; CASILLAS; ACEDO, 2013). This constitutes a problem since it is the "when" element that largely defines internationalization processes (KUTSCHKER; BAURLE; SCHMID, 1997). This oversight is paradoxical for a body of knowledge that claims to differentiate itself from economic-based internationalization approaches by being dynamic (JOHANSON; VAHLNE, 1990, 2009).

In order to help correct this shortcoming and make room for "putting process (back) in" (WELCH; PAAVILAINEN-MANTYMAKI, 2014, p. 2), we suggest that it is necessary to re-embed the internationalization process of the firm in temporality (ZAHEER; ALBERT; ZAHEER, 1999) by making one or more of the following dimensions explicit: interval (CASILLAS; ACEDO, 2013), order (KUTSCHKER; BAURLE; SCHMID, 1997), rhythm (VERMEULEN; BARKEMA, 2002) or pace (e.g. CHETTY; JOHANSON; MARTIN, 2014; HILMERSSON, 2014; HILMERSSON; JOHANSON, 2016). This means analyzing how these dimensions shape the internationalization process of the firm. Following our research question, we chose the pacing dimension for closer examination.

\subsection{PACE OF INTERNATIONALIZATION PROCESSES}

Inspired by the literature on born-global firms (ZANDER; McDOUGALL-CORVIN; ROSE, 2015) or new international ventures (OVIATT; MCDOUGALL, 1994), research on pace emphasizes time to internationalize (DIMITRATOS; JOHNSON, PLAKOYIANNAKI; YOUNG, 2016). It focuses on the time interval between the firm inception and the firm's first experience in a particular foreign market. The major conclusion is that such firms start internationalizing activities as soon as they are founded (ZANDER; McDOUGALL-CORVIN; ROSE, 2015). Moreover, they accelerate their internationalization processes by entering multiple foreign markets simultaneously (WANG; SUH, 2009).

However, pace of internationalization processes does not necessarily equate with time to internationalize (CASILLAS; ACEDO, 2013). For example, Chetty, Johanson and Martin (2014) forcefully suggest that this time interval is only a particular facet of the pace of internationalization processes. There are other facets such as post-entry pace that deserve further attention to advance our understanding of the pace of the internationalization process of the firm (DIMITRATOS; JOHNSON; PLAKOYIANNAKI; YOUNG, 2016). This is the avenue pursued in this article.

According to recent reviews (CASILLAS; ACEDO, 2013; CHETTY; JOHANSON; MARTIN, 2014; HILMERSSON; JOHANSON, 2016), research on pace is in its infancy. 
Scholars are still disputing how pace is conceptualized, as well as how it should be measured. Chetty, Johanson and Martin (2014, p. 633) argue that the concept of pace is "[...] under researched and scholars have provided little guidance for firms about how to manage and measure speed of internationalization".

This is particularly true for SMEs from emerging economies (KHAVUL; PÉREZ-NORDTVEDT; WOOD, 2010; LIN, 2012). Such firms usually rely on exporting for operating abroad (MARTINEAU; PASTORIZA, 2016). Moreover, they lack experience and heuristics (CHILD; HSIEH, 2014), and suffer from institutional voids in their home countries (JORMANAINENN; KOVESHNIKOV, 2012). As a result, SMEs from emerging economies face difficulties not only in accelerating their internationalization processes, but also in promoting modal shifts into more advanced modes. Because these constrains are attenuated for MNEs, in particular those originated from developed economies, they turn out to be the most obvious choice for studying the pace of internationalization processes (CASILLAS; MORENO-MENÉNDEZ, 2014).

Broadly, pace refers to a particular distance covered within a particular time unit (CASILLAS; ACEDO, 2013). This definition is, however, translated into different measures of pace of internationalization processes. For example, Petersen and Pedersen (1999) suggest a measure that includes resource commitment, degree of irreversibility of resources and time elapsed since the firm's first international experience. More recently, Casillas and Moreno-Menéndez (2014, p. 91) have measured pace "as the number of days between the focal operation and immediately prior operation of the same firm".

Notwithstanding, Casillas and Acedo (2013) and Chetty, Johanson and Martin (2014) forcefully suggest that the content validity of pace is higher when the measure connects a specific variation within a particular indicator to a specific unit of time. Casillas and Acedo (2013) and Hilmersson and Johanson (2016) propose indicators such as commercial intensity, commitment of foreign resources and breadth of international markets. Chetty, Johanson and Martin (2014), in turn, suggest that the state of internationalization is an appropriate indicator, which, in their study, is illustrated by the number of countries, the number of entry modes, the number of employees in international activities, the number of languages used, and the entry mode with foreign investment.

Another controversial issue relating to pace refers to the starting point for measuring pace of the internationalization processes. Prashantham and Young (2011) and Hilmersson and Johanson (2016) propose the foundation of the firm as ground zero. They argue that this point of departure takes into account both earlier (time to internationalize) as well as later (time after internationalization) phases in the internationalization process of the firm. By contrast, Petersen and Pedersen (1999) and Casillas and Acedo (2013) consider the first international experience of the firm as a starting point on the basis that this event is usually regarded as a watershed in the growth trajectory of the firm. Research on foreign market entry mode lends sound support to this line of reasoning (HENNART; SLANGEN, 2015).

Finally, scholars also diverge on the unit of analysis. Following Casillas and Acedo (2013), there are two possible levels: within a particular foreign market and across foreign markets. In the former, the pace of the internationalization process of the firm is measured separately for each foreign market where the firm has a presence. Consequently, the pace of the internationalization of the firm as a whole is calculated by averaging out the results of 
the pace obtained for each foreign market. In the latter, the pace of the internationalization process of the firm is calculated regardless of the foreign markets where the firm operates. In this case, a state in a particular indicator is compared with a previous state within that indicator irrespective of the markets where the firm is spatially embedded (CASILLAS; MORENO-MENÉNDEZ, 2014). This is the option most frequently selected in IB empirical studies (e.g. HILMERSSON; JOHANSON, 2016).

These three issues are inextricably interlinked meaning that researchers must face them when conducting research on the pace of the internationalization process of the firm. In this article, pace is measured by considering the firm's first experience in each foreign market it enters. In addition, our measure of pace takes into account the modal shifts proposed by Benito, Petersen and Welch $(2009,2011)$ per foreign market (numerator) in relation to the number of years the firm has operated in each of such foreign markets (denominator). Thus, we measure the pace of modal shifts in internationalization processes. Finally, we preserve the sequences of modal shifts in each foreign market the firm has ventured in order to compare their paces. Thus, our unit of analysis is within the foreign market. In the next section, we justify such choices.

\section{METHODOLOGY}

We do not consider pace as either a dependent or independent variable in internationalization processes, but one of their building blocks (KUTSCHKER; BAURLE; SCHMID, 1997). Accordingly, pace illustrates the third element of internationalization processes ("when"), thus making the temporal dimension of these processes explicit (CASILLAS; ACEDO, 2013).

Such approach requires contextual, processual and longitudinal data (EISENHARDT, 1989). According to Langley, Smallman, Tsoukas and Van de Ven (2013), a qualitative approach developed by means of a retrospective longitudinal, embedded case study fits well with such requirements. In addition, research on pace of internationalization processes is "[...] still wide open for future research" (CASILLAS; ACEDO, 2013, p. 16). At this stage, a qualitative approach is very useful for developing and refining themes and constructs (EISENHARDT; GRABNER; SONENSHEIN, 2016), as well as creating typologies or categories of a particular phenomenon (GEORGE; BENNETT, 2005).

We developed our qualitative, retrospective longitudinal, embedded case study of a Brazilian medium-sized firm, henceforth called CZM. In order to select CZM we searched for firms that operated in as many foreign markets as possible. Yet, we sought for firms that displayed "long" internationalization processes. Most importantly, we needed free access to secondary and primary data. As pointed out by Langley (1999), building sequences of events requires data that are not easily retrieved. Further, these data must be triangulated in order to minimize bias stemming from memory. In such situation, convenience plays a big role in selecting the empirical case.

Indeed, the first author had personal contacts with individuals from the upper echelons of one of the most internationalized Brazilian manufacturing firms. Not only did 
such contacts help get consent from the firm for carrying out research, but they also granted us free access to secondary and primary data. (Table 1).

In terms of secondary data, 282 pages were gathered from the following sources

Table 1 - Secondary data

\begin{tabular}{|c|c|c|}
\hline Source & Unit & Quantity \\
\hline $\begin{array}{l}\text { Contracts, addendum, and correspondence letters } \\
\text { with sales representatives }\end{array}$ & Pages & 45 \\
\hline Reports and production plans of the subsidiary & Pages & 61 \\
\hline Catalog of products & Pages & 44 \\
\hline Sales registers & Pages & 7 \\
\hline Contact information of international customers & Pages & 4 \\
\hline Power-Point slides & Pages & 121 \\
\hline CZM and CZM-USA's websites & Websites & 2 \\
\hline
\end{tabular}

Source: Authors.

Primary data came from 13 semi-structured, face-to-face interviews carried out in two waves between June and February 2014 in three countries: Brazil, the US and the UK (Table 2). All interviews were transcribed verbatim, resulting in 173 pages of double-spaced text. Such interviews were supported by a protocol containing questions concerning the foreign markets selected by the firm, reasons behind this choice, modal shifts in each foreign market and more importantly, dates of each modal shift in each foreign market mentioned by the interviewees.

Table 2 - Interviews

\begin{tabular}{ccc}
\hline$\#$ & Position & Duration (hours) \\
\hline 1 & Founder & $0: 17$ \\
2 & CEO (1st interview) & $1: 27$ \\
3 & International Sales Director & $1: 09$ \\
4 & Country Manager - USA (1st interview) & $1: 17$ \\
5 & President of the Board & $0: 18$ \\
6 & Manufacturing Director & $0: 24$ \\
7 & Sales Manager Brazil & $1: 14$ \\
8 & Sales Managers USA & $0: 25$ \\
9 & International Salesman & $0: 17$ \\
10 & Former Sales Manager Brazil & $0: 50$ \\
11 & UK Sales Representative & $0: 36$ \\
12 & CEO (2nd interview) & $0: 27$ \\
13 & Country Manager - USA (2st interview) & $0: 18$ \\
\hline
\end{tabular}

Source: Authors. 
Our initial step of data analysis was to write as many documents as the number of foreign markets mentioned by the interviewees. Based on the interview excerpts, we outlined the internationalization process of CZM in each foreign market the firm had entered. Subsequently, we included, in these documents, extracts from secondary data that were more closely related to such foreign markets.

We found various discrepancies. For example, some interviewees mentioned that CZM had sold drills in both the Bolivian and the Mexican markets, whereas others did not remember about these foreign sales. We addressed such discrepancies by triangulating the data derived from the interviews with archival data and internal reports - in particular the sales register -, and by contacting some interviewees by either e-mail or phone (YIN, 1984). We ended up with 16 documents containing a preliminary account of CZM's internationalization process in 16 foreign markets.

Subsequently, we built 16 sequences of events (ABBOTT, 1992, 2001), namely, the entry mode and the subsequent modal shifts in each foreign market we had strong evidence that the firm had actually ventured (BENITO; PETERSEN; WELCH, 2009). We considered not only single, but also a package of modes (BENITO; PETERSEN; WELCH, 2011), the latter being broadly defined as a combination of individual modes for servicing a foreign market.

In reviewing the literature on modal shifts in the internationalization process of the firm, Benito, Petersen and Welch (2009, p. 1456) contend that prior studies tend to view modes as "lumpy, unitary entities". Thus, what is effectively considered is only full modal shifts comprising changes from a specific mode (e.g. direct exporting) to another different mode (e.g. production subsidiary). As a result, a number of modal shifts in the internationalization process of the firm are left unexamined (PEDERSEN; PETERSEN; BENITO, 2003). Similarly, packages of modes are usually disregarded (BENITO, PETERSEN; WELCH, 2011).

Reasoning in this way, Petersen, Benito, Welch and Asmussen (2008) suggest categorizing modal shifts according to the activities of the value chain performed by a firm, the governance forms employed (e.g. equity vs. non-equity) and the foreign markets in which those activities are deployed. Later, Benito, Petersen and Welch (2009) develop four broad types of modal shifts: within-mode change, mode role change, mode addition or deletion and full mode change. Within-mode change is the subtlest form of modal shift, and often represents an adjustment in the mode, such as switching sales representatives. Mode role change denotes the addition or subtraction of an activity to the mode in a same foreign market. Adding upstream activities such as R\&D to a production subsidiary is an example of mode role change. Mode addition or deletion is an increase or reduction in the number of modes used by the firm such as adding direct exporting to licensing. Full mode change represents a complete change of the mode, such as shifting from direct exporting to production subsidiary.

In this article, we follow this suggestion. Hence, we initially identified the entry mode and searched for any within-mode change, mode role change, mode addition or deletion, and a full mode change undertaken either sequentially or simultaneously in each of the foreign markets where CZM has operated. 
Having mapped out the sequences of modal shifts (the "how" element), we turned to the "why" element of these internationalization processes (CASILLAS; ACEDO, 2013). In this regard, we aimed to discover why CZM switched modes (or not) in each of its internationalization processes. Our major source of evidence was the interviews, since we explicitly asked the individuals why CZM had changed a particular mode in a given foreign market.

Then, we analyzed the "when" aspect of the internationalization process, this being the aspect of the internationalization process of the firm examined in this article. Following the aforementioned categorization of modal shifts (BENITO; PETERSEN; WELCH, 2009, 2011), we identified when CZM changed modes (i.e. month and year) and the length of time it took to promote such changes.

We rewrote all of the documents by placing emphasis on how, why and when CZM had entered each foreign market, as well as on how, why and when it engaged in modal shifts in those foreign markets. To our narrative, we added excerpts from the interviews and secondary data in order to lend support to our analysis. We then sent the reports to the CEO, the country manager in the USA, and the country manager in Brazil for comments and criticisms. In general, they agreed that the reports were an accurate portrayal of the internationalization of CZM.

Our next step was to calculate the pace of the internationalization process of the firm. As discussed earlier, this measure is best represented by a ratio between a particular dimension of change and a specific unit of time. In our case, the dimension of change is the number of modal shifts CZM carried out in a particular foreign market. For example, in Argentine, CZM added indirect exporting to direct exporting (mode addition) only once. This corresponds to one modal shift in that foreign market. It is worth making the general point that measuring pace of modal shifts as such implies focusing only on how often a firm switches modes. Thus, this does not include the magnitude or direction of modal shifts, such as increase or decrease in resource commitment ${ }^{3}$.

The definition of the unit of time was nested within two further specifications: the starting point and the unit of analysis. Because the concept of pace in the SME internationalization process is still controversial (CHETTY; JOHANSON; MARTIN, 2014; HILMERSSON; JOHANSON, 2016), we found no clear recommendations in the literature on how to measure it. As a result, we decided to calculate the pace of the internationalization process of CZM by referring to previous works. Following Casillas and Acedo (2007) and Casillas and Moreno-Menéndez (2014) we chose the firm's first international experience as the starting point. Based on Hilmersson (2014) and Hilmersson and Johanson (2016), we considered firm inception. But in accordance with the rationale offered by Casillas and Acedo (2013), we selected the firm's first experience in each foreign market.

We contrasted these results with our 16 internationalization processes and concluded that the starting point should be the firm's first experience in each foreign market. Consequently, the unit of analysis should be each foreign market.

3. We thank an anonymous reviewer for calling our attention to this point. 
These parameters led us to measure pace as follows: the number of modal shifts in relation to the number of years elapsed from the first experience of the firm in each foreign market.

$$
P_{j}=\frac{\sum_{j} M}{\Delta_{(\mathrm{Y}-\mathrm{y})_{\mathrm{j}}}}
$$

where $P$ is pace, $j$ is any given foreign market, $M$ is modal shift, $Y$ is the ending point of the internationalization process, and $y$ is the year of foreign market entry.

For example, we mentioned earlier that CZM carried out one modal shift in Argentina. Since it entered that market in 1994, the number of years considered here is 19 years. Therefore, the pace of CZM internationalization in Argentina is 0.05 (one modal shift divided by 19 years).

A note on the ending point of the internationalization processes is deserved. In our case, this point is the same for all processes, corresponding to the last year we have data about the internationalization processes within CZM: 2013.

We defined this ending point based on an informal conversation with the country manager of the United States. Specifically, we noticed that after entry, CZM was not involved with exporting another piece of equipment to some foreign markets such as Singapore and Ecuador for 17 years and nine years respectively. Neither did it change the foreign market entry mode (indirect exporting and direct exporting respectively) in that period.

We then asked the interviewee whether we should consider that CZM no longer operated in those markets. He explained that, for CZM, operating in some foreign markets means not only exporting equipment, but also providing after-sales services and supplying spare parts. In addition, we noticed that in some foreign markets such as Venezuela CZM only exported a second piece of equipment 10 years after entry. Based on these pieces of evidence, we concluded that CZM still operates in the foreign markets analyzed in this article ${ }^{4}$.

Our last step in the data analysis involved undertaking a comparative analysis in order to find out similarities and differences across the sub-cases. We discovered that these processes followed different paces, leading us to categorize them into three distinct groups (GEORGE; BENNETT, 2005). The first group refers to internationalization processes wherein CZM had not changed the servicing mode within a "long" time span $(\mathrm{N}=12)$. The second group corresponds to internationalization processes marked by a single modal shift within a "long" time span $(\mathrm{N}=3)$. The third group includes a single internationalization process. In such process, we observed a number of changes during the time length analyzed in this

4. As a sort of robustness check, we studied different ending points. We considered that CZM exited a foreign market (mode deletion) if it had not exported equipment in five, seven and ten years. Our results are virtually the same. We still obtain three categories of internationalization processes distinguished in terms of pace of modal shifts. However, the number of internationalization processes classified into each category changes. Depending on the time window, some internationalization processes previously categorized into Unmovable have to be classified into Inert. 
article. Therefore, these distinct groups point to a category of internationalization processes characterized by post-entry zero pace; a category in which the internationalization process follows a slower pace in terms of modal shifts; and finally, a category of internationalization process in which the development in the foreign market is more accelerated.

\section{THE INTERNATIONALIZATION OF CZM ${ }^{5}$}

CZM was founded as early as the 1950s as a reseller of salvage construction machinery. Having already repositioned itself as a foundation equipment manufacturer (e.g. drilled shafts, continuous flight augers and pile drivers) it had its first international experience in the late 1980s. In the following 27 years, CZM entered 16 foreign markets, each one representing an internationalization process. Such processes are grouped into three categories according to the pace of modal shifts: Unmovable Internationalization Process, Inert Internationalization Process and Accelerated Internationalization Process (Table 3).

\subsection{UNMOVABLE INTERNATIONALIZATION PROCESS}

The Unmovable Internationalization Process category comprises 12 internationalization processes. CZM entered nine foreign markets through direct exporting (Paraguay, Colombia, Australia, Ecuador, Venezuela, Nigeria, El Salvador, the Dominican Republic and Russia), two foreign markets through indirect exporting (Colombia and Singapore) and one foreign market through joint venture (Italy). We explain the entries in these foreign markets as follows: i) the customer itself contacted CZM interested in equipment, thus characterizing a reactive internationalization; ii) deals originated in trade shows in which CZM participated; and iii) opportunities developed either by CZM itself or by an independent sales agent. Entry in Italy happened to facilitate businesses between CZM's US subsidiary and its main supplier.

Although the foreign market entry modes selected by CZM vary, the internationalization processes classified in this category show a common pattern of sequential moves: The firm does not make any change in or/and within modes. This means that the firm exported more pieces of equipment and spare parts, as well as serviced local customers through the mode selected in the market entry. In this sense, the post-entry pace of these internationalization processes is zero.

For example, CZM was contacted by a Colombian firm and directly exported two drills in 1993 to that market. Even though it sold eight more drills over the years, it did not change the entry mode. Similarly, entry into India took place in 1995 when CZM sold a drill to a customer who, two years earlier, had contacted the firm in an international trade show. After seven years, CZM directly exported four more pieces of equipment to different customers. This means that the foreign market entry mode remained unchanged.

5. Due to space concerns, we report an abridged account of CZM's internationalization processes. The full report is available from the authors at request. 
Interestingly, no similarity emerges within this group in relation to either date of entry or foreign market. This means that the Unmovable Internationalization Processes are bounded by neither entry timing nor geography. For example, internationalization processes with zero pace were triggered in earlier (e.g. Paraguay and Colombia) as well as later (e.g. Russia and Italy) phases in the internationalization of CZM. They were also spatially embedded in a number of foreign markets spanning countries from South America (e.g. Colombia and Venezuela) to Central America (e.g. the Dominican Republic and El Salvador) as well as from Africa to Asia (e.g. Nigeria and India).

When we asked the interviewees why CZM had not changed the initial foreign market, a number of factors emerged. They referred to the firm level of satisfaction with the entry mode, lack of firm experience and resources, long geographic distance and language barrier. The satisfaction with the entry mode is emphasized by the sales manager in Brazil when discussing the internationalization process in the Dominican Republic, "[...] the exporting process was very simple as well, we sent technicians, it was always very easy to send spare parts, exporting the equipment, I handled all the documentation, very easily". The negative aspects are summarized by the international sales director, when discussing the use of an agent in Singapore, "[...] there was a huge gap in terms of technology; even painting the equipment, and how to export. We didn't have much experience with shipping [processes] either". The CEO also explained the reason for using mostly exports in Latin American countries, "Brazil was always on the edge, so we were always trying to export, we traveled around Latin America, we wanted to sell [equipment]".

Market size is, however, the factor which was most emphasized by the interviewees to explain why the entry mode remained unchanged. According to them, in foreign markets such as Paraguay, Australia, Ecuador, Venezuela, Nigeria, and El Salvador, the construction industry comprises a handful of firms that import equipment sporadically. Thus, there was no perceived need to change the initial foreign market entry mode. The CEO illustrates this when discussing the internationalization process in El Salvador, "It's tough when the country is small. We went to El Salvador. It was so much work, and it only has one foundation company".

Although CZM remained with the initial mode, we noticed that the interviewees pointed out that to a greater or lesser degree, the firm had learnt a great deal about those foreign markets with time. The firm had acquired knowledge about: i) how to make deals in such foreign markets; ii) how to adapt equipment to the specific needs of local customers; iii) how to write contracts and deal with exporting paperwork; and iv) how to make adjustments and refine the extant servicing modes without changing them. The internationalization process in Colombia illustrates this, as reported by the sales manager in Brazil,

We had two large customers there, so we exported some heavy equipment, we started to export large equipment. The technical support after sales was better, they realized it. [...] So we developed an advantage, with technical support after sales, equipment that we were able to develop, a technology that was good for them. [Interviewee \#7]

The fact that CZM learnt a great deal about operating in those foreign markets with time signifies that sticking with the initial mode did not impede learning in the foreign 
markets. Thus, the pace of modal shifts did not follow the pace of learning about foreign markets in the Unmovable Internationalization Processes.

\subsection{INERT INTERNATIONALIZATION PROCESS}

The second group is dubbed Inert Internationalization Process and comprises three internationalization processes that involve a single modal shift after entry.

CZM entered Argentina and England through direct exporting, and Uruguay through indirect exporting. The former resulted from the efforts of CZM to prospect customers through either local visits (Argentina) or ads in a trade magazine (England). The international sales director told: "We put an ad on a magazine named GeoDrilling, he [the English customer] saw it and called us". The latter has its roots in an independent sales agent who identified an opportunity in that market. The CEO told: "And there was a friend [of the founder] who worked with exporting [...] he took our product brochures and distributed them [throughout Latin America]. [...] and we exported a truck mounted drilling rig to Uruguay".

After entry, CZM promoted a single modal shift in each foreign market over the years. In both Argentina and England CZM added indirect exporting to direct exporting (mode addition). Since then, CZM has operated in both foreign markets through a package of modes comprising indirect and direct exporting. In Uruguay, CZM replaced indirect exporting by direct exporting (full mode change).

Serendipity explains why CZM added indirect exporting to direct exporting in Argentina. An independent sales agent sold equipment to a local customer and continued to make deals in that foreign market. He earned a commission per equipment sold. The modal shift in England is explained by network ties. CZM met an English sales agent through one of its customers. The agent was interested in establishing a formal representation, to which CZM agreed. Nonetheless, sales to its first customer in England were not covered by the contract, so CZM continued exporting directly to that customer. By contrast, CZM was not satisfied with the Uruguayan sales representative and decided to carry out exporting activities on its own. Following these modal shifts, CZM deemed that extant modes were adequate for operating in those three foreign markets. In both Uruguay and England, the modal shift was carried out shortly after entry. By contrast, in Argentina it took 14 years for CZM to switch the foreign market entry mode. As calculated here, the pace of Inert International Processes is 0.057 , corresponding to an average change every 18 years.

The internationalization of CZM in England is a nice example. The firm entered the English market in 1999 by selling a drill to a firm that saw an ad in a trade magazine. Two years later, CZM started selling equipment through indirect exporting by accrediting a sales representative. Since 2001, CZM has been operating in this foreign market with a package of modes (indirect and direct exporting). During this period, CZM has deepened its knowledge about the English market by reinforcing existing customer relationships as well as developing a number of new relationships. In total, it sold 33 drills, twelve to its first customer.

Similar to the Unmovable Internationalization Processes, we found that learning in Inert Internationalization Processes has increased with time. CZM has become more knowledgeable about local customers, sales representatives and internationalization routines. 
Nonetheless, it carried out a single modal shift in a long time span. Thus, the pace of modal shifts did not follow the pace of learning about foreign markets in Inert Internationalization Processes. The English sales agent, for example, illustrated how CZM developed throughout their relationship,

Especially in the beginning, everything we have ever bought, really, we had to modify and update and upgrade, improve, so we did a lot of things like that right at the beginning. [...] So, that was a lot of, yes, from this direction, going to you, a lot of information and improvements that we did, we showed you how we did it and you learnt a little bit from us I think. [Interviewee \#11]

\subsection{ACCELERATED INTERNATIONALIZATION PROCESS}

The last group, Accelerated Internationalization Process, refers to a single process displaying a higher pace. This means that the firm progressed more rapidly than it did in the processes classified in the previous group. Accordingly, the average pace of the Accelerated Internationalization Process is 0.43 , corresponding to a modal shift every 2.3 years.

This is illustrated by the internationalization process in the US. Dating back to 1999, the firm entered the American market through indirect exporting. After selling six more drills through this distribution channel, in 2002, an American firm came into contact for licensing a technology developed by CZM. By granting the license, it started operating in the US with a package of modes (first modal shift).

Five years later, in 2007, CZM was involved with another modal shift. It added a new sales representative to the mode package (second modal shift). Shortly after, in addition to sales and marketing activities this sales representative started performing assembling activities. This mode role change corresponds to the third modal shift undertaken in the US.

Three more modal shifts follow. In 2012, CZM set up a production subsidiary (fourth modal shift), since it decided to fully exploit opportunities in the US market, which values American made equipment. After that, the firm started prospecting local customers on its own, because it was not satisfied with the performance of its sales representatives. As a result, it started selling directly to American customers (fifth modal shift). The sixth and last modal shift in the US took place in 2013, when one of the sales representatives started performing financing activities rather than just sales and marketing activities. This was necessary because the American market demanded rentals with purchase options (RPO) and leases, which demand capital, rather than direct sales. Overall, CZM sold 55 different types of drills to a number of American customers.

Some of our interviewees pointed out that the more CZM learnt about the US market, the more it generated continuous sales. The more sales increased the more it switched modes. Such modal shifts involved more resource commitment (e.g. from indirect exporting to a complex combination of modes comprising direct exporting, licensing sales and production subsidiary). This, in turn, enabled CZM to learn more about how to operate in the US. Although both learning and modal shifts in the US were inextricably linked, we lack evidence of whether their rates evolved concurrently. 


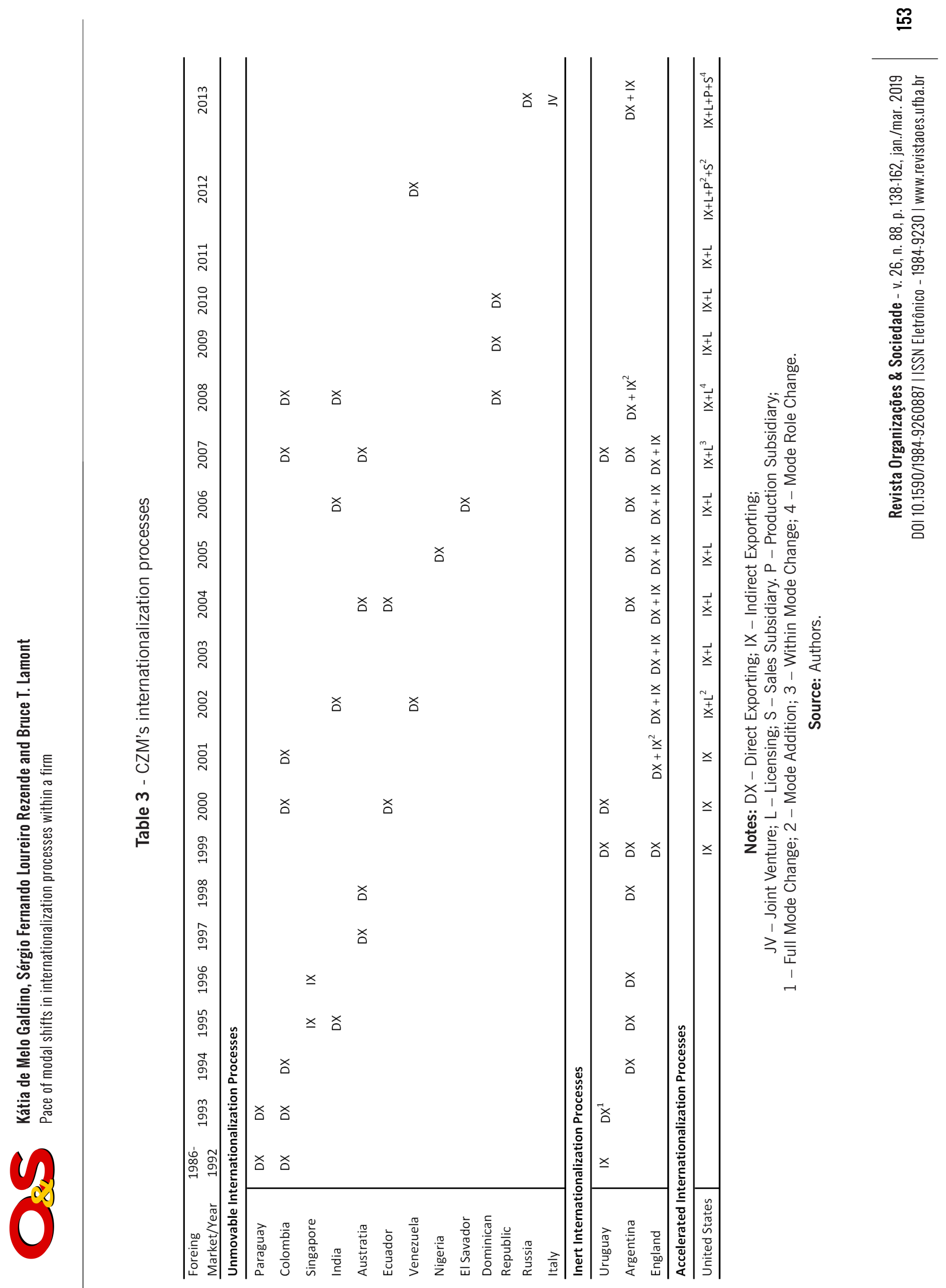




\section{PACES OF INTERNATIONALIZATION PROCESSES}

Our results show that the internationalization processes triggered by CZM in 16 foreign markets during nearly three decades can be grouped into three categories. In the first category, Unmovable Internationalization Process, we include internationalization processes that show no modal shift after the entry mode is selected. This means that the firm still operates in each of those foreign markets by using the initial entry mode (SWOBODA; ELSNER; OLEJNIK, 2015). The second group comprises internationalization processes wherein a single modal shift was undertaken over time. In this case, the firm evolves more slowly by implementing a unique mode change (PEDERSEN; PETERSEN; BENITO, 2002). We name these internationalization processes as Inert. Finally, the last group includes accelerated internationalization processes in which a number of modal shifts are carried out over the period of time (PEDERSEN; PETERSEN, 1999).

This categorization suggests that continuous, long-term internationalization processes within a firm vary considerably according to the pace of modal shifts (MORGAN-THOMAS; JONES, 2009; CASILLAS; ACEDO, 2013), going from processes that show no change after the foreign market entry to processes that go through various modal shifts. Hence:

P1: The internationalization processes within a firm can be distinguished according to the pace of modal shifts into Unmovable Internationalization Processes, Inert Internationalization Processes and Accelerated International Processes.

We remark that the Unmovable and the Inert Internationalization Processes are scarcely portrayed in the IB studies (CASILLAS; ACEDO, 2013). Moreover, they stand in sharp contrast with the bulk of the research on the internationalization of the firm from a behavioral standpoint.

First, the literature pays little attention to Unmovable Internationalization Processes, which consist of internationalization processes that display no change. Therefore, it has little to say about SMEs that enter a particular foreign market and remain operating in it in the long term without necessarily switching modes (SWOBODA; ELSNER; OLEJNIK, 2015).

In fact, modal shifts have attracted much more interest than mode continuation (BENITO; PEDERSEN; WELCH, 1999). Perhaps this is because change in modes is assumed to be "commonplace and something to be expected" (PEDERSEN; PETERSEN; BENITO, 2002, p. 327). Hence, switching costs are minimized as the firm learns how to operate in a particular foreign market (PETERSEN; PEDERSEN, 1999). Modal shifts turn out to be easier, less costly and less risky (PEDERSEN; PETERSEN; BENITO, 2002). Our results challenge this view. Rather than an assumption, we suggest that whether and how often an internationalizing firm switches modes with time in a given foreign market is an open question.

Second, even though research concentrates on internationalization processes that exhibit modal shifts (HILMERSSON; JOHANSON, 2016) it usually does not differentiate between different paces of internationalization processes within a firm (ACEDO; CASILLAS, 
2007; CASILLAS; ACEDO, 2013) such as those that evolve more slowly from those that develop faster. Since the temporal dimension is usually disregarded (CASILLAS; MORENO; ACEDO, 2012), it is often implicitly assumed that they can be analyzed through a similar lens.

A handful of conceptual and empirical works lend support to our findings that Unmovable and Inert Gradual Internationalization Processes represent legitimate and distinct types of internationalization processes as far as pace of modal shifts is concerned. For example, Anderson and Coughlan's (1987) influential paper on exporting channels suggests that they are difficult to change. Jull and Walters (1987) found that firms only rarely induce changes in modes. On average, it took the selected firms 13 years to change the foreign market entry mode. Similarly, Pedersen, Petersen and Benito (2002) found that two thirds of the sampled firms remained with the same mode after five years.

Because Unmovable and Inert Internationalization Processes have hardly been reported in the literature, these results remind us that research about such processes is urgently needed. We recommend formulating research questions that are markedly different from those addressing faster internationalization processes. For example, we found that entry mode does not change in the Unmovable Internationalization Process group. In this case, should we not ask why the firm is stuck with its initial choice? Are there factors that obstruct or deter firms from making mode change? If so, our investigation should tackle obstacles to change rather than change drivers (BENITO; PEDERSEN; WELCH, 2009).

A closely related argument is that changes in the Inert Internationalization Process group seem to be an exception rather than the norm, with a notion that resonates with structural inertia (HANNAN; FREEMAN, 1984). For this group, instead of asking why and how things change, should we not study why the firm is involved with few mode changes in the long term? What is the interplay between inducements and deterrents for modal shifts? Are there classes of modal shifts in the Inert Internationalization Processes that are more difficult to change?

Differently put, these results suggest that changes in modes are not necessarily the outcome of internationalization processes (JOHANSON; MARTIN, 2015); or, if they are, they may be rarer and less rapid than generally assumed (BENITO; PEDERSEN; WELCH, 2009). Hence:

P2a: Modal shifts in some internationalization processes within a firm (i.e. Unmovable Internationalization Processes) are inexistent.

P2b: Modal shifts in some internationalization processes within a firm (i.e. Inert Internationalization Processes) are one-off.

In analyzing the pace of internationalization processes within a firm, unexpectedly we found a possible mismatch between the pace of learning and the pace of modal shifts in foreign markets, in particular in the processes categorized as Unmovable and Inert. Precisely, CZM learnt a great deal in foreign markets by, for instance, reinforcing extant relationships (exploitation) or engaging in new relationships (exploration) with customers or representatives (BECHMAN; HAUNSCHILD; PHILIPS, 2004). In doing so, it developed new 
routines for operating internationally and refined extant modes (CASILLAS; ACEDO, 2013). However, it did not modify the foreign market entry mode. This situation corresponds to our Unmovable Internationalization Process.

In other foreign markets, CZM learnt more rapidly than it switched modes. In such cases, we found a single modal shift during a long time span (i.e. from 13 years to more than 20 years). According to our qualitative evidence, it is doubtless that CZM acquired more knowledge in the period when modal shifts remained unchanged. Thus, the pace of modal shifts did not follow the pace of learning. This situation corresponds to our Inert Internationalization Processes.

These findings open up the possibility of disentangling learning from modal shifts in foreign markets (FIGUEIRA-DE-LEMOS; HADJIKHANI, 2014). Rather than taking for granted the assumption that the more the firm learns in a particular foreign market the more it commits tangible resources to it (JOHANSON; VAHLNE, 1977), our results dissociate the pace of modal shifts from the pace of learning in foreign markets. (JOHANSON; MARTIN, 2015). Hence:

P3: The pace of modal shifts differs from the pace of learning in Unmovable and Inert Internationalization Processes.

In sum, we show that even within a single firm, internationalization processes vary according to the pace of modal shifts. That is, there may be multiple internationalization processes inside a single firm that follow distinct paces. This result suggests that the internationalization of the firm as a whole is much more intricate and complex than portrayed in the extant literature (HADJIKHANI; HADJIKHANI; THILLENIUS, 2014). It seems to be a combination of a number of internationalization processes following diverse paces (KUTSCHKER; BAURLE; SCHMID, 1997). Therefore, rather than a single pace, future research should consider multiple paces of modal shifts in the internationalization processes within a firm.

\section{CONCLUSION}

We started this article claiming that the "when" element of internationalization processes has not received due attention in studies of the internationalization of the firm (CASILLAS; MORENO; ACEDO, 2012), in particular SMEs from emerging markets (JORMANAINENN; KOVESHNIKOV, 2012; LIN, 2012). Based on this research gap, we analyzed how a particular temporal dimension - pace -, could be used to distinguish the internationalization processes within a firm.

Unlike previous studies, which viewed pace as either a dependent or an independent variable (e.g. ACEDO; JONES, 2007; HILMERSSON, 2014, HILMERSSON; JOHANSON, 2016), we considered pace as of the building blocks of the internationalization of the firm (KUTSCHER; BAURLE; SCHMID, 1997. Being an intrinsic part of internationalization processes, we analyzed pace accordingly. We showed how pace of modal shifts shaped such processes (WELCH; PAAVILAINEN-MANTYMAKI, 2014). As a result, we rediscovered see- 
mingly ignored patterns of internationalization processes, as well as rethought the relation between the pace of modal shifts and the pace of learning in the internationalization of the firm.

Based on our findings, we contribute to the literature in a number of ways. First, we suggest that internationalization processes within a firm can be distinguished according to the pace of modal shifts. In this article we propose three categories: Unmovable Internationalization Processes, Inert Internationalization Processes and Accelerated Internationalization Processes. Second, we show that Unmovable and Inert Internationalization Processes represent distinct categories of internationalization as far as pace of modal shifts is concerned. As argued earlier, they are often neglected in IB empirical studies, thus compromising our knowledge of the internationalization of the firm from a behavioral standpoint. In this vein, we posit that a more nuanced understanding of both of them requires research questions that are markedly different from those usually tackled by IB scholars. Third, we challenge the taken-for-granted assumption of pace of learning vis-à-vis modal shifts. Rather than being equivalent, we document a mismatch between paces of modal shifts and learning in a given foreign market (CHETTY; JOHANSON; MARTIN, 2014) in particular for the processes categorized into Unmovable and Inert. Fourth, we analyze the pace of internationalization processes that unfold within a single firm. This means that the internationalization of the firm comprises multiple paces of internationalization processes in the foreign markets in which they are embedded (MAITLAND; ROSE; NICHOLAS, 2005; NACHUM; SONG, 2011). We suggest that this paints a rather novel picture of the internationalization of the firm in terms of the pace of modal shifts.

However, this study has a number of limitations. The research method used here eschews statistical generalization in favor of the deep understanding that a clinical case study provides (YIN, 1984). In addition, our findings are bounded by a number of contextual factors such as time and country of origin. In this regard, we draw attention to the boundary condition stemming from CZM type of business. This firm manufactures heavy equipment used in the construction industry. Different from consumer goods, this type of product is not exported continuously to foreign markets where the construction industry is either incipient or composed of few firms. This may be a powerful modal shift deterrent. We also placed emphasis on a particular temporal dimension of the internationalization process: pace. However, this dimension can be illustrated by other indicators such as interval (CASILLAS; ACEDO, 2013), order (KUTSCHER; BAURLE; SCHMID, 1977), and rhythm (VERMEULEN; BARKEMA, 2002). Consequently, new patterns of internationalization processes will eventually be unveiled if one of the other indicators is taken into account. Finally, although we used different measures of the pace of modal shifts based on previous studies and selected the one that more closely reflects our qualitative results, we acknowledge that other measurements are possible and might have led to somewhat different results.

\section{ACKNOWLEGMENTS}

Sérgio Rezende is grateful to CNPq (Grant Number - 302843/2015-9) for financial support. We thank Luis Araújo for comments on earlier drafts of the manuscript. We are 
highly indebted to the anonymous reviewers for their comments. The remaining errors are ours.

\section{REFERENCES}

ABBOTT, A. From Causes to Events. Sociological Methods and Research, v. 20, p. 428455, 1992. 2001.

. Time Matters: On Theory and Methods. Chicago: The University of Chicago Press,

ACEDO, F.; CASILLAS, J. Age at Entry in International Markets of Spanish SMEs: Entrepreneurial and Institutional Determinants. International Journal of Entrepreneurial Behavior and Research, v. 13, n. 3, p. 130-150, 2007.

ACEDO, F.; JONES, M. Speed of Internationalization and Entrepreneurial Cognition: Insights and a Comparison between International New Ventures, Exporters and Domestic Firms. Journal of World Business, v. 42, p. 236-252, 2007.

ANDERSON, E.; COUGHLAN, A. International Market Entry and Expansion via Independent or Integrated Channels of Distribution. Journal of Marketing, v. 51, p. 71-82, 1987.

BECHMAN, C.; HAUNSCHILD, P. ; PHILLIPS, D. Friends or Strangers? Firm-specific Uncertainty, Market Uncertainty, and Network Partner Selection. Organization Science, v. 15, n. 3, p. 259-275, 2004.

BENITO, G.; PEDERSEN, T.; PETERSEN, B. Foreign Operation Methods and Switching Costs: Conceptual Issues and Possible Effects. Scandinavian Journal of Management, v. 15, n. 2, p. 213-229, 1999.

BENITO, G.; PETERSEN, B.; WELCH, L. Towards More Realistic Conceptualisations of Foreign Operation Modes. Journal of International Business Studies, v. 40, n. 9, p. 14551470, 2009.

. Mode Combinations and International Operations: Theoretical Issues and an Empirical Investigation. Management International Review, v. 51, n. 6, p. 803-820, 2011.

BILKEY, W.; TESAR, G. The Export Behavior of Smaller-sized Wisconsin Manufacturing Firms. Journal of International Business Studies, v. 8, n. 1, p. 93-98, 1977.

CASILLAS, J.; ACEDO, J. Speed in the Internationalization Process of the Firm. International Journal of Management Reviews, v. 15, p. 15-29, 2013.

CASILLAS, J.; MORENO, A.; ACEDO, F. Path Dependence View of Export Behaviour: A Relationship between Static Patterns and Dynamic Configurations. International Business Review, v. 21, p. 3, p. 465-479, 2012.

CASILLAS, J.; MORENO-MENÉNDEZ, A. Speed of the Internationalization Process: The Role of Diversity and Depth in Experiential Learning. Journal of International Business Studies, v. 45, p. 85-101, 2014.

CHETTY, S.; JOHANSON, M.; MARTIN, O. Speed of Internationalization: Conceptualization, Measurement and Validation. Journal of World Business, v. 49, p. 633-650, 2014. 
CHILD, J.; HSIEH, L. Decision Mode, Information and Network Attachment in the Internationalization of SMEs: A Configurational and Contingency Analysis. Journal of World Business, v. 49, n. 4, p. 598-610, 2014.

COVIELLO, N. ; MUNRO, H. Network Relationships and the Internationalisation Process of Small Software Firms. International Business Review, v. 6, n. 2, p. 1-26, 1997.

CUERVO-CAZURRA, A. Sequence of Value-added Activities in the Internationalization of Developing Country MNEs. Journal of International Management, v. 13, n. 3, p. 258-277, 2007.

DIMITRATOS, P. ; JOHNSON, J.E.; PLAYKOYIANNAKI, E.; YOUNG, S. SME internationalization: How does the opportunity-based international entrepreneurial culture matter? International Business Review, v. 25, p. 1211-1222, 2016.

EISENHARDT, K. Building Theories from Case Study Research. Academy of Management Review, v. 14, n. 4, p. 532-550, 1989.

EISENHARDT, K.; GRABNER, M.; SONENSHEIN, S. Grand Challenges and Inductive Methods: Rigor without Rigor Mortis. Academy of Management Journal, v. 59, n. 4, p. 1113-1123, 2016.

FIGUEIRA-DE-LEMOS, F.; HADJIKHANI, A. Internationalization Processes in Stable and Unstable Market Conditions: Towards a Model of Commitment Decisions in Dynamic Environments. Journal of World Business, v. 49, n. 4, p. 332-349, 2014.

FORSGREN, M.; HOLM, U.; JOHANSON, J. Knowledge, Networks and Power: The Uppsala School of International Business. England: Palgrave Macmillan, 2015.

FORTANIER, F.; TULDER, R. Internationalization Trajectories: A Cross-country Comparison: Are Large Chinese and Indian Companies Different? Industrial \& Corporate Change, v. 18, n. 2, p. 223-247, 2009.

GAO, G.; PAN, Y. The Pace of MNEs' Sequential Entries: Cumulative Entry Experience and the Dynamic Process. Journal of International Business Studies, v. 41, n. 9, p. 15721580, 2010.

GEORGE, A.; BENNETT, A. Case Studies and Theory Development in the Social Sciences. Cambridge, Mass: MIT Press, 2005.

HADJIKHANI, A.; HADJIKHANI, A.; THILLENIUS, P. The Internationalization Process Model: A Proposed View of Firms' Regular Incremental and Irregular Non-incremental Behaviour. International Business Review, v. 23, n. 1, p. 155-168, 2014.

HANNAN, M.; FREEMAN, J. Structural Inertia and Organizational Change. American Sociological Review, v. 49, p. 149-164, 1984.

HENNART, J-F.; SLANGEN, A. Yes, We Really Do Need More Entry Mode Studies! A Commentary on Shaver. Journal of International Business Studies, v. 46, p. 114-122, 2015.

HILMERSSON, M. Small and Medium-sized Enterprises Internationalization Strategy and Performance in Times of Market Turbulence. International Small Business Journal, v. 32, p. 4, p. 386-400, 2014. 
HILMERSSON, M.; JOHANSON, J. Speed of SME Internationalization and Performance. Management International Review, v. 56, n. 1, p. 67-94, 2016.

HOHENTHAL, J.; JOHANSON, J.; JOHANSON, M. Network Knowledge and Business-Relationship Value in the Foreign Market. International Business Review, v. 23, n. 1, p. 4-19, 2014.

JOHANSON, M.; MARTIN, O. The Incremental Expansion of Born Internationals: a Comparison of New and Old Born Internationals. International Business Review, v. 24, p. 476-496, 2015.

JOHANSON, J.; VAHLNE, J.-E. The Internationalization Process of the Firm: Model of Knowledge Development and Increasing Foreign Market Commitments. Journal of International Business Studies, v. 8, p. 23-32, 1977.

JOHANSON, J.; VAHLNE, J. The Mechanism of Internationalization. International Marketing Review, v. 7, n. 4, p. 11-24, 1990.

. The Uppsala Internationalization Process Model Revisited: From Liability of Foreignness to Liability of Outsidership. Journal of International Business Studies, v. 40, n. 9, p. 1411-1431, 2009.

JOHANSON, J.; WIEDERSHEIM-PAUL, F. The Internationalization of the Firm: Four Swedish Cases. Journal of Management Studies, October, p. 305-322, 1975.

JONES, G.; KHANNA, T. Bringing History (back) into International Business. Journal of International Business Studies, v. 37, n. 4, p. 453-468, 2006.

JORMANAINENN, I.; KOVESHNIKOV, A. International Activities of Emerging Market Firms. Management International Review, v. 52, n. 5, p. 691-725, 2012.

JULL, M.; WALTERS, P. The Internationalization of Norwegian firms: A Study of the UK Experience. Management International Review, v. 39, n. 4, p. 9-25, 1987.

KHAVUL, S.; PÉREZ-NORDTVEDT, L.; WOOD, E. Organizational Entrainment and International New Ventures from Emerging Markets. Journal of Business Venturing, v. 25, p. 104-199, 2010.

KUTSCHKER, M.; BAURLE, I.; SCHMID, S. International Evolution, International Episodes and International Epochs: Implications for Managing Internationalization. Management International Review, v. 37, n. 2, p. 101-124, 1997.

LANGLEY, A. Strategies for Theorizing from Process Data. Academy of Management Review, v. 24, n. 4, p. 691-710, 1999.

LANGLEY, A.; SMALLMAN, C.; TSOUKAS, H.; VAN DE VEN, A. Process Studies of Change in Organization and Management: Unveiling Temporality, Activity, and Flow. Academy of Management Journal, v. 56, n. 1, p. 1-13, 2013.

LAUFS, K.; SCHWENS, C. Foreign Entry Mode Choice of Small and Medium-Sized Enterprises: A Systematic Review and Future Research Agenda. International Business Review, v. 23, p. 1109-1126, 2014. 
LIN, W-T. Family Ownership and Internationalization Processes: Internationalization Pace, Internationalization Scope, and Internationalization Rhythm. European Management Journal, v. 30, p. 47-56, 2012.

MAITLAND, E.; ROSE, E.; NICHOLAS, S. How Firms Grow: Clustering as a Dynamic Model of Internationalization. Journal of International Business Studies, v. 36, n. 4, p. 435-451, 2005.

MARTINEAU, C.; PASTORIZA, D. International Involvement of established SMEs: A systematic review of antecedents, outcomes and moderators. International Business Review, $\mathrm{v}$. 25, n. 2, p. 458-470, 2016.

MORGAN-THOMAS, A.; JONES, M. Post-entry Internationalization Dynamics Differences between SMEs in the Development Speed of their International Sales. International Small Business Journal, v. 27, n. 1, p. 71-97, 2009.

NACHUM, L.; SONG, S. The MNE as a Portfolio: Interdependencies in MNE Growth Trajectory. Journal of International Business Studies, v. 42, n. 3, p. 381-405, 2011.

OVIATT, B.; McDOUGALL, P. Toward a Theory of International New Ventures. Journal of International Business Studies, v. 25, n. 1, p. 45-64, 2004.

PAJUNEN, K.; MAUNULA, M. Internationalisation: A Co-evolutionary Perspective. Scandinavian Journal of Management, v. 24, n. 3, p. 247-258, 2008.

PEDERSEN, T.; PETERSEN, B.; BENITO, G. Foreign Operation Mode Change: Impetus and Switching Costs. International Business Review, v. 11, n. 2, p. 325-345, 2002.

PETERSEN, B.; BENITO, G.; WELCH, L.; ASMUSSEN, C. Mode Configuration Diversity: A New Perspective on Foreign Operation Mode Choice. In: GRIFFTH, S.; CAVUSGIL, T.; HULT, G.; LEWIN, A. (Eds.). Thought Leadership in Advancing International Business Research. London: Palgrave, p. 57-78, 2008.

PETERSEN, B.; PEDERSEN, T. Fast and Slow Resource Commitment to Foreign Markets: What Causes the Difference? Journal of International Management, v. 5, n. 2, p. 73-91, 1999.

PRASHANTHAM, S.; YOUNG, S. Post-entry Speed of International New Ventures. Entrepreneurship Theory \& Practice, March, p. 275-292, 2011.

RUGMAN, A.; VERBEKE, A.; NGUYEN, P. Fifty Years of International Business Theory and Beyond. Management International Review, v. 51, n. 6, p. 755-786, 2011.

SHAVER, J. Do We Really Need More Entry Mode Studies? Journal of International Business Studies, v. 44, p. 23-27, 2013.

SWOBODA, B.; ELSNER, S.; OLEJNIK, E. How do Past Mode Choices Influence Subsequent Entry? A Study on the Boundary Conditions of Preferred Entry Modes of Retail Firms. International Business Review, v. 24, p. 506-517, 2015.

VAHLNE, J-E.; JOHANSON, J. The Uppsala Model on Evolution of the Multinational Business Enterprise: From Internalization to Coordination of Network. International Marketing Review, v. 30, n. 3, p. 189-210, 2013. 
VERMEULEN, F.; BARKEMA, H. Pace, Rhythm, and Scope: Process Dependence in Building a Profitable Multinational Corporation. Strategic Management Journal, v. 23, n. 7, p. 637653, 2002.

WANG, Y.; SUH, C. Towards a Re-conceptualization of Firm Internationalization: Heterogeneous Process, Subsidiary Roles and Knowledge Flow. Journal of International Management, v. 15, n. 4, p. 447-459, 2009.

WELCH, C.; PAAVILAINEN-MANTYMAKI, E. Putting Process (Back) In: Research on the Internationalization Process of the Firm. International Journal of Management Reviews, $v$. 16, p. 2-23, 2014.

YEUNG, H. The Socio-Spatial Constitution of Business Organizations: A Geographical Perspective. Organizations, v. 5, n. 1, p. 101-128, 1998.

YIN, R. Case Study Research: Design and Methods. Beverly Hills, CA: Sage, 1984.

ZAHEER, S.; ALBERT, S.; ZAHEER, A. Time Scales and Organizational Theory. Academy of Management Review, v. 24, n. 4, p. 725-741, 1999.

ZANDER, I. Technological Diversification in the Multinational Corporation: Historical Evolution and Future Prospects. Research Policy, v. 26, n. 2, p. 209-227, 1997.

ZANDER, I.; McDOUGALL-CORVIN, P. ; ROSE, E. Born Globals and International Business: Evolution of a Field of Research. Journal of International Business Studies, v. 46. p. 27-35, 2015.

Submission date: 12/09/2016.

Approval date: 07/07/2017.

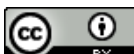

Creative Commons Atribuição 4.0 Internacional

Note: you can find this paper in Portuguese at http://www.revistaoes.ufba.br. 